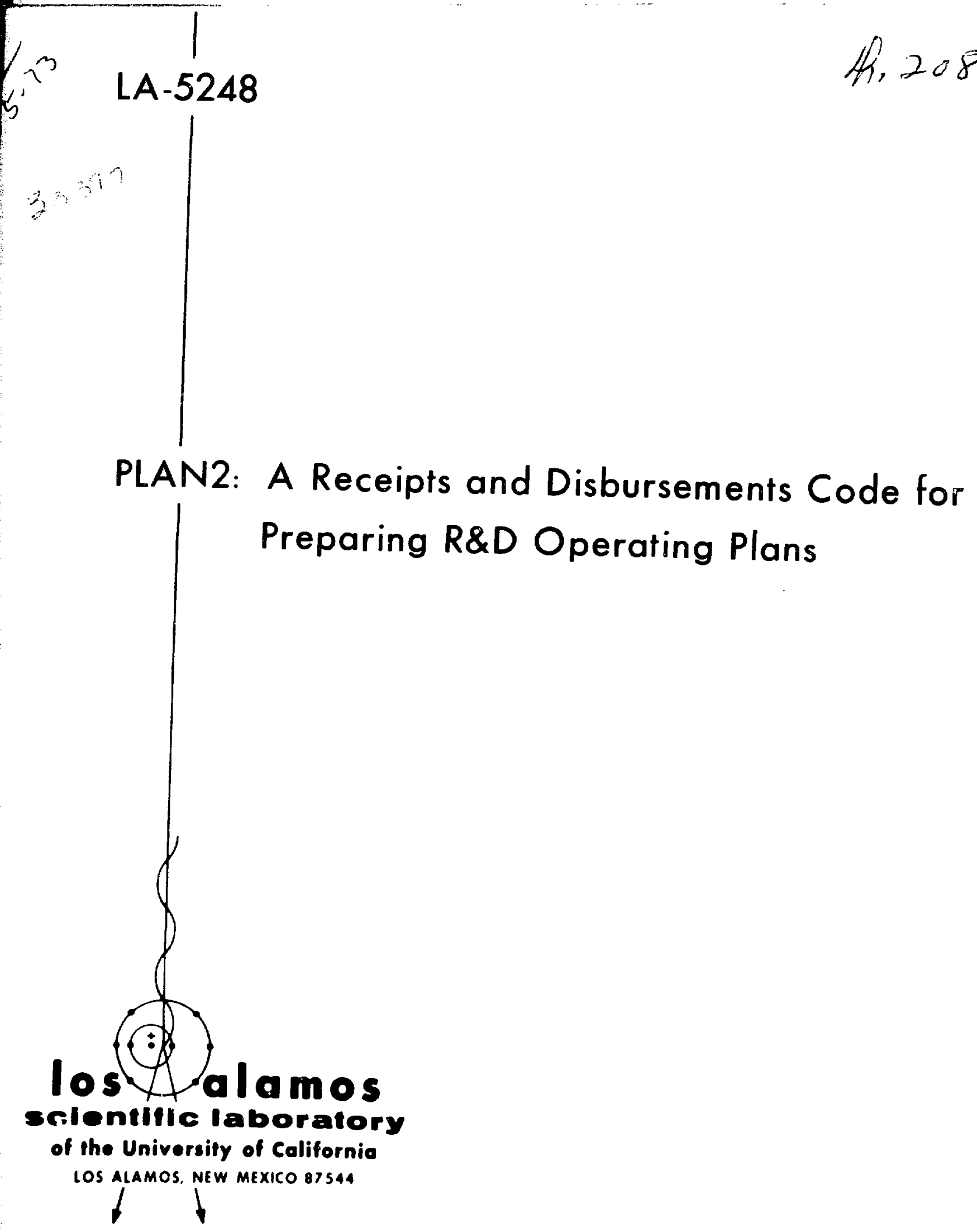


This report was prepared as an account of work sponsored by the United States Government. Neither the United States nor the United States Atomic Energy Cormmission, nor any of their employees, nor any of their contractors. subcotrtractors, or their employees, makes any warranty. express or im. plied, of assumes any legai liability or responsibility for the aceuracy, com. pleteness or usefulness of any information. apparatus, product or process dis. closed. or represents tha: its use would not intringe privately owned rights.

Printed in the United Siates of Ameriea. Arabble trom

Nationst Technical Intosmation Service

U. S. Department of Commerce

5285 Port Roy Hoad

Springliels, Vitginia 22151

Price: Printed Cony stom, Mierotiche $\$ 0.95$

1,00 


\section{PLAN2: A Receipts and Disbursements Code for Preparing R\&D Operating Plans}

by

D. R. Harris

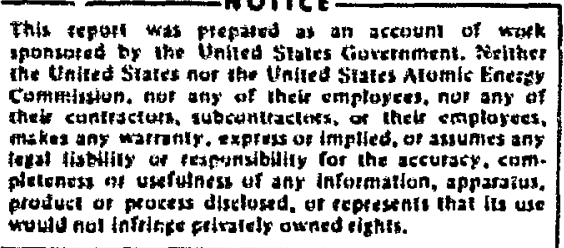
would nal infritipe fritsiely owned eights. 


\section{Contents}

\begin{tabular}{|c|c|}
\hline & Abstract \\
\hline \multirow{6}{*}{$\begin{array}{l}\text { Section I. } \\
\text { Section II. } \\
\text { Section III. } \\
\text { Scceion IV. }\end{array}$} & Introduction \\
\hline & Data and Calculations. \\
\hline & Input \\
\hline & Output \\
\hline & Acknowledgment \\
\hline & References \\
\hline \multirow{6}{*}{ 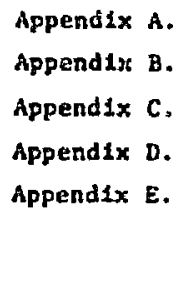 } & PLAN2 Varlable Definfelons \\
\hline & Sample Input for PLAN2 for a Group \\
\hline & Sample Output for PLAN2 for a Group \\
\hline & Sample Input for PLAN2 for a Program \\
\hline & Sample Output for PLAN2 for a Program \\
\hline & 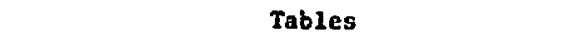 \\
\hline
\end{tabular}


PLAN2, A RECEIPTS AND DISBURSEMENTS CODE FOR PREPARING RSD OPERATING PLANS

by

D. R. Harr1s

ABSTRACT

PLAN2, a FORTRAN-IV code for the CDC and UNIVAC computers, prepares recelpts and disburserents operating plans for management planning of research and development organizations. A particular, but representative, relationship of management, costing, and funding structures is assumed.

\section{INTRODUCTION}

Management planning of research and development (R6D) programs requires anticipation of capability for carrying out progran obligations. Thus, forecasts of personnel and other resources must be projected into the future as constrained by costs and funds. Such profectlons are referred to as operating plans and are part of the well-developed discipline of Internal managerent accounting. ${ }^{1}$ Opersting planis are useful in examining alternative use of RED resources, in making proposals and commitments, and in supporting proposed changes in personnel and other resources.

operating plans for R\&D must conform in format to Internal accounting practlce used at the Installation where the research and development is to be administered. Th1s requircment arises because of the necessity for a formated data base from which to extrapolace and because of the recurrent need to check operating plens againgt reported fact. On the other hand, operating plans for research and development organizations share certaln comen features and simplicities in contrast to forecasting for manufa turing or marketing organizations. ${ }^{1}$ In particular, the product of research and development of ten consists of reported discovertes and related accomplishments and 18 not easily subject to fiscal account1ng. Hence, optimization techniques for R\&D are not as relevant as is simple forecasing. In addition, RSD costs, other than for capital equipment, reflect personnel levels, and these can be forecast more simply than can costs for raw materials, etc., required for manufacturing and marketing organlzations. Although there ere considerable varlations in costing procedures from one RdD Installation to another, there is a certaln uniformity in funding procedure insofar as funds are solicleed, recelved, and accounted for the technical program. Thus, it is possible to relate RdD capabilities (personnel, equipsent, services, and materials) in a reasonably general way with commlted and ant:c1pated funding and with known and anticlpated costs.

The so-called receipts and disbursements method for flacal forecating ${ }^{1}$ is approprlate for preparing RSD operating plans between yearly balance sheets. To be compatible with funding procedures and to be useful in managenent planning, the forecast must extend over one fiscal year and, in most cases, through the next fiscel year. Th1s approach requires "soft" f Inanclal data such as anticipated funding levels, cost-of-11ving adfustments, etc., and can be crit1c1zed on this count. Nevertheless, reasonable use of "herd" existing accounting data can be made and systematized in a communicable computer code. 
PLAN2 is a recelpts and disbursements accountIng forecast code tc prepare operating plans for RGD organizations in the framework of the accountIng system current at the Los Alamos Scientific Laboratory. In its reported form, the code accesses accounting data from card 1nput. The code consists of about 500 statement ifnes and is written in FORTRAN-IV to be compatible with CDC and UNIVAC computers.

Required data and calculations for PLAN2 are described in Sec. II. Input and output are described in Secs. III and IV, respectively. Code variable definltions are given in Appendix A. Inputs and outputs are 11sted in Appendixes $B$ through $E$ for two test problems. These 1llustrate the treatment of management planning requirements for two complementary forms of R\&D organizaticn; one the funded program described earller and one the administratively unifled group or collection of personnel, equipment, etc., that w1ll be referred to here simply as a group.

\section{DATA AND CALCULATIONS}

It has already been noted that the product of R\&D is difficult to quantify in fiscal or other units. Hence, it is not clear how an operating plan for R\&D can be optimized in the usual product sense by linear programing, ${ }^{2}$ by optimization based on sensitivity analysis, ${ }^{3}$ or by some other techn1que. However, alternative reasonable allocations of funds for salaries, wages, materlals, services, computer time, travel, etc., can be profected and compared. The PLAN2 cade prepares operating plans In th1s sense, 1.e., a proposed plan and antic1patied or proposed funding are input, and the code conputes projected costs and balances.

Research and developnent funds ordinarily are solicited for a technical program and, when received, are accounted from a "funding center" that we shall refer to as a program. Clearly, a progrom can have a variety of local names and characterist1cs. As costs (described next) accumulate, they are charged to the program and are subtracted from the program balance. For present purposes, an R\&D program is an accounting entity with a proper balance, as well as being a technical management enticy with goals, schedules, and other fectures.
The way costs are collected and are ultimately assigned to the program can vary greatly. We shall assume that, as the R\&D work progresses, costs are incurred and charged directly or Indirectly to a "cost center." To administer costs in relation to R\&D capability, 1t is useful, though not necessary, that the cost center be equated with the administratively unified group described ear1ler. The PLAN2 code assumes that this is the case. As is true for the program, a group can have a variety of local names and characteristics.

W1th these assumptions, the fundamental unit for preparing an operating plan must be the cost center-funding center or, as we have equated cost center and group and funding center and program, the group-program. The group-progran entity thus is that part of a particular administratively unifled group that is supported by a particular progrom. Operating plans for group-progrom entities then can be collected In many ways: (a) for all the groupprogroms in a program to examine total capability, proper balance, etc.; (b) for all the group-programs In a group to examine comparative costs and to reallocate resources, etc.; and (c) for the groupprograms in administrative-accounting entitles larger than the group or program.

To prepare an operating plan, a PLAN2 user f1rst projects for each required group-progrom entity the planned monthly levels of staffing in terms of professional staff members (full-time equivalent) and of other employees (full-time equivalent). Known accounting data from previous wonths are read in for each group-progrcom. An initlal balance at the beginning of the current fiscal year is read in for each group-progrom and, if operating plans are to be collected for a program, for the program as well. Although a balance has not the signiflcance for a group-progran entity that it has for a progrom, still it reflects cumulative costs in the groupprogram. Therefore, a balance for each groupprogram 18 computed and pritited by PLAN2. PLAN2 profects for two or more fiscal years between balance sheets at the end of flscal years. The PLAN2 user also supplies data on anticipated or proposed new funds, anticipated cost-of-living adjustments, fund carry-overs from one fiscal year to the next, and cost computation options, PLAN2 then computes costs and balances as follows. 
Profected costs for salarles and wages for a particular group-progrom entity are computed from the profected personnel levels by one of three options selected by the control parameter KONSAL.

Suppose that the user 1s preparing an operating plan for a group. If KONSAL equals 3 , the projected salary cost, SAL(IM,IE), is computed as input, PAV$\mathrm{SAL}$, times the number of professional staff members, SMFTE(IM,IE), for all forecasted months, IM, and for group-progrom entities in the group. Simliarly, the profected wage cost, WGS(IM,IE), 1s computed as input, PAVWGS, times the number of other employees, $\operatorname{GSFTE}(I M, I E)$. If KONSAL equals 2 , the input constants, PAVSAL and PAVWGS, are replaced by the average salary per professional staff member and the average wages per other employee, respectively, averaged over all the group-progrom entities in the group for the last month, LAMON, with known accounting data. If KONSAL equals 1 , the input constante, PAVSAL and PAVWGS, are replaced by the average salary per professional staff member and the average wages per other employee, respectively, averaged over all the group-progran entities in the group and also averaged over all known accounting months, $(1$, LAMON) .

Now suppose the PLAN2 user is preparing a forecast for a progrom. If KONSAL equals 3 , the profected salary cost, SAL(IM,IE), is computed as input, AVSALP(IE), times the projected number of professlonal ataff members, SMFTE(IM,IE). Similarly, the projected wage cost, WGS (IM,IE), is computed as Input, AVWGSP(IE), times the forecast, GSFTE(IM,IE). When KONSAL equals 2 or 1 , the projected salarles and wages for the group-program entity, IE, are computed as appropriate projected personnel levels times cost per person figures determined for that group-progrom entity alone for the last accounted month or are averaged over all accounted months, respectively.

Two aspects of the calculation are noteworthy. First, salary and wage costo per person are compuced as averaged over all group-progran entities In a group. Second, auppose a new group-program entity ia to be added to a program operating plan prepared using KONSAL equal to 1 or 2 . In this case, no wage or salary Information has yet been established for the group-progrom entity, so the average over other group-program entities in the progrom 18 used. Perhaps it would have been better to use instead wage and salary information for the group to which this group-progrom entity belongs, but it cannot be assumed that the required accounting data have been read into the code.

Indirect costs may include plant maintenance, general laboratory overhead, and other costs not directly charged to the group-program. Indirect monthly costs (burden) are forecast in PLAN2 as a factor times the sum of salaries and wages for the group-program entity for that wonth. The factor is selected by an input conirrol parameter, KONFAC. If KONFAC is 3 , then the factor is an input quantity, PFIND. If KONFAC equals 2, the value computed from the last accounted month, LAMON, is used. If KONFAC equals 1 , the value averaged over all accounted months is used.

The KONSAL and KONFAC options are detalled in Appendix $A$ and in comment lines in the PLAN2 code. Several "materlals and services" (M\&S) cost categorles, NC In number, are charged directly to the group-progran. These include, at the option of the PLAN2 user, materlals, travel, computer services, certain kinds of equipment, etc. Capital equipment is not included, nor are its costs forecast by PLAN2. Monthly costs in each M\&S category are forecast as factor times the number of personnel "celling polnts" In the group-program for that month. The number of ceiling points is equal to SMFTE(IM,IE) plus a constant CPFAC times GSFTE(IM,IE), and CPFAC is set in PLAN2 to be $1 / 2$, a value which has been found to yleld reasonable forecasts. " The multiplying factor noted above is determined as an average over the already accounted months or, if for a new groupprogram, is determined frous the value for the precading group-progrom in the fob.

Certal: monthly M\&S category costo are exceedingly difficult to forecast, except in a timeaverage sense as, for example, for travel, for computer costs, and for certain types of equipment. Because of these and other Inevitakle uncertaintiev In forecasting, PLAN2 eschews such niceties as, for example, computing wages as being proportional to the number of working days in each month.

Finally, monthly costs and a balance axe forecast for each group-progrom entity and summed over

\footnotetext{
*The PLANl code, not reported, computed salaries plus wages and, hence, Indirect as well, ow a "celling point" basis.
} 
all the group-progrom entities in the group or program as selected by the PLAN2 user.

III. INPUT

Input for PLAN2 is listed in Table I in terms of code variable names defined in Appendix A. Known accounting data are input from cards which can be punched from the laboratory's accounting data base. Options are defined in Appendix A.

Illustrative Inputs are listed in Appendixeg $B$ and $D$ for two test problems. In one test problem, projections are summed over the group-progrom entities in a group. In the other test problem, projections are summed over the group-program entities in a program. In the 1llustrative cases, only two M\&S categorles are treated; any number (NC) could have been Included by the code user. For explanaticn of the 1llustrative test problems, refer to Sec. IV.

\section{OUTPUT}

Outputs for the two 111ustrative test problems for PLAN2 are 1isted in Append1xes $C$ and $E$. Actual and projected data extend over two flsca! years for three hypothetical group-progrom entities GXX1-PXX1, $G \times X 1-P X X 2$, and GXX2-PXX1. In Append1x $C$, costs and personnel are collected for group GXX1, and, In Appendix $D$, cost $B$, personnel, and balances are collected for progrom PXX1. Managers of groups GXXi and $G \times X 2$, as well as managers of progroms FXX1 and PXX2, might be Involved in "thrashing out" these operating plans. By printing compactly professional staff member,, SM(FTE), other employees, GS(FTE), SALARY AND WAGES, INDIRECT, Materials and Services categorles CAT1, СAT2, .., CATNC, COST and BALANCE, the user can see at a glance the features and consequences of the forecast.

It was noted in Sec. II that options can be selected for the forecast calculations. The PLAN2 output states all the selected options efther 1mplicitly or explicitly. Explicit option statements Include: (a) Program or group operating plans are differentiated by the title; (b) The projection techniques for AVSSM/SMFTE (as well as the same technique for AVWGS/GSFTE) and IND/SAL are 11sted at the foot of the printed operating plan as Ident1fied by KONSAL and KONFAC. Implicit option statements Include: (a) The last month with known ac-
TABLE I

INPUT FOR PLAN2

\begin{tabular}{|c|c|c|}
\hline Item & Format & Varlab1e \\
\hline 1 & 8A9 & GPDEN/2A9, FDATE/A9 \\
\hline 2 & $12 I 6$ & $\begin{array}{l}\text { NE, NC, LAMON , NFY, KONSAL, KONFAC, NMCOL, } \\
\text { (IMCOL (II) , II =1, NMCOL) }\end{array}$ \\
\hline 3 & $6 E 12.6$ & $\begin{array}{l}\text { PAVSAL, PAVWGS, PFIND, (COLFAC (II) , II=1 } \\
\text { NMCOL) }\end{array}$ \\
\hline \multirow{11}{*}{$\begin{array}{l}4 \\
5 \\
\epsilon \\
7\end{array}$} & 1216 & KONPRO, (KONCAR (IE), IE $=1, \mathrm{NE})$ \\
\hline & $6 \mathrm{E} 12.6$ & (AVSALP (IE), IE l, NE) If KONPRO.NE.0 \\
\hline & 6E12.6 & (AVWGSP (IE), IE $=1, \mathrm{NE}$ ) If KONPRO.NE.0 \\
\hline & $6 \mathrm{E} 12.6$ & (SMFTE $(\mathrm{IM}, \mathrm{IE}=1), \mathrm{IM}=1, \mathrm{NM})$ \\
\hline & $6 \mathrm{E} 12.6$ & (GSFTE (IM, IE=1), IM=1, MM) \\
\hline & $6 \mathrm{E} 12.6$ & (SMFTE (IM, IE=2), IM=1, NM) \\
\hline & $6 \mathrm{E} 12.6$ & $(\operatorname{GSFXE}(I M, I E=2), T M=1, N M)$ \\
\hline & & $\begin{array}{lll}\cdot & \cdot\end{array}$ \\
\hline & & $\cdot$ \\
\hline & $6 \mathrm{E} 12.6$ & 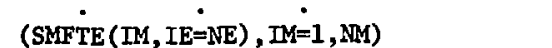 \\
\hline & $6 \mathrm{E} 12.6$ & $(\operatorname{GSFTE}(\mathrm{IM}, \mathrm{IE}=\mathrm{NE}, \mathrm{IM}=1, \mathrm{NM})$ \\
\hline \multirow[t]{12}{*}{8} & $6 \mathrm{E} 12.6$ & $\operatorname{ACENT}(\mathrm{IE}=1), \operatorname{APROG}(\mathrm{IE}=1)$ \\
\hline & $6 \mathrm{E} 12.6$ & BAIIN (IE $=1)$ for $I M$ \\
\hline & $6 \mathrm{E} 12.6$ & $\begin{array}{l}\operatorname{SMFTE}(I M, I E=1), \operatorname{GSFTE}(I M, I E=1), \\
\operatorname{ASL}(I M, I E=1)\end{array}$ \\
\hline & $6 \mathrm{E} 12.6$ & $\begin{array}{l}\text { WGS }(I M, I E=1), \operatorname{DIN}(I M, I E=1) \\
\quad(\operatorname{SM}(I M, I E=1, I C) I C=1, N C)\end{array}$ \\
\hline & & $\therefore \quad . \quad$ \\
\hline & & - \\
\hline & & • \\
\hline & $6 \mathrm{E} 12.6$ & $\operatorname{ACENT}(I E=N E), \operatorname{APROG}(I E=N E)$ \\
\hline & $6 \mathrm{E} 12.6$ & BALIN (IE $=N E)$ \\
\hline & $6 \mathrm{E} 12.6$ & $\begin{array}{l}\text { SMFTE (IM, IE }=\text { NE), } \operatorname{GSFTE}(I M, I E=1), \\
\text { SAL }(I M, I E=1)\end{array}$ \\
\hline & $6 \mathrm{E} 12.6$ & $\begin{array}{l}\text { WGS (IM, IE=1), DIN (IM , IE=1) } \\
\quad(W M(I M, I E=1, I C) I C=1, N C)\end{array}$ \\
\hline & & for entity IE=1 \\
\hline \multirow[t]{14}{*}{9} & 1216 & $\begin{array}{l}\text { NMFUND, (IMFUND (II, II=1, NMGUUND) } \\
\text { FUNDS (IMFUND (II=1),IE=1) }\end{array}$ \\
\hline & & FUNDS (IMFUND (II=2), IE=1) \\
\hline & & $\dot{0} \quad \dot{0}$ \\
\hline & & \\
\hline & $6 \mathrm{E} 12.6$ & FUNDS (IMFUND (II=MMFUND (IE=1), IE=1) \\
\hline & & 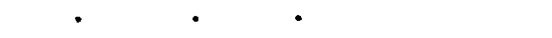 \\
\hline & & $\cdot$ \\
\hline & & for entity $I E=N E$ \\
\hline & $12 I 6$ & MMPUND, (IMFUND (II), II $=1$, NMFUND) \\
\hline & $6 E 12.6$ & FUNDS (IMFUND (II=1), IE=NE) \\
\hline & $6 \mathrm{E} 12.6$ & FUNDS (IMFUND (II=2), IE=NE) \\
\hline & & $\begin{array}{rll}\bullet & \bullet & \bullet\end{array}$ \\
\hline & & $\because \quad \quad \dot{ }$ \\
\hline & $6 \mathrm{E} 12.6$ & FUNDS (IMFUND (II = MMFUND (IE $=\mathrm{NE}$ ), IE $=\mathrm{NE}$ ) \\
\hline
\end{tabular}

counting data is that preceding the forecast month; (b) Those group-progroms whose funds do not carry over from year to year are 1dentified by zero initlal balances going into each fiscal year. 


\section{ACKNOWLEDGEMENT}

The author is greatly indebted to W. E. Crowe for helpful advice and encouragement.

\section{REFERENCES}

1. A. R. Coleman, Financial Accounting, a General Management Approach (John Wiley \& Sons, Inc., New York, NY, 1970).
2. L. A. Welsch and R. M. Syert, Eds., Management Dectoion Making (Penguin Books, Inc., Balt1more, Md, 1971).

3. A. Rappaport, "Sensitivity Analysis in Decision Making," Accounting Review, pp 441-456 (July 1967). 
PLANZ PREPARES OPERATING PLANS FOR GROUP-PROGRAM ENTITIES AND COLLECTS BY GROUP (COST-CENTER), PROGRAM (FUNDING CENTER), ETC.

DEF INITIONS

ACENT (IE) =GROUP (CGST CENTFR) ID FOR ENTITY IE, EG, GXX)

APROG (IE) =PROGRAM (FUNO CENTER) ID FOR ENTITY IE. EG, PXXI

AVFAC (IM) =RATIO OF INDIRECT TO SALARY IN MONTH IM

AVSSM (IM, IF) = AVERAGE SALARY PER PROFESSIONAL STAFF MEMBER IN MONTH IM FOR ENITY IE

AVSSM(IM,NE+1) = AVERAGE SALARY PER PROFESSIONAL STAFF MEMBER AVEHAGED OVERALL GROUP-PROGRAM ENTITIES IN JOB

AVWGS (IM, IE) = AVERAGE WAGES PER GS(FTE) IN MONTH IM FOR ENTITY IE

AVWGS (IM,NE II) = AVERAGE WAGES PER GS (FTE) IN MONTH IM AVERAGED OVER ALL GROUP-PROGPAM ENTITIES IN JOB

AVSALP(IE) =PROJECTED INPUT SALARY PER PROFESSIONAL STAFF MEMBER FOR ENTITY IE

AVWGSP (IE) = PROJECTED WAGFS PER GS(FTE) FOR ENTITIY IE

BAL (IM,IE) = BALANCF AT END OF MONTH IM FOR GROUP-PROGRAM ENTITY IE

BALIN(IE) = INITIAL BALANCE IN ACCOUNT FOR ENTITY IE

COLFAC (II) =II-TH COST OF LIVING FACTOR

COST (IM,IF) $=$ COST FOR ENTITY IF. IN MONTH IM

CP $(I M$. IE $)=C E I L I N G$ POINTS IN ENTITY JE FOR MONTH IM COMPUTED AS SMFTE PLUS CPFAC GSFTE

CPFAC =FACTOR USED IN CEILING POINT COMPUTATION

DIN $(I M, I F)=I N D I R E C T$ COST IN MONTH IM FOR ENTITY IE

FDATE $=$ FORECAST DATE, EG, $12 / 26 / 72$

GPOEN=GROUP, PROGRAM, DIVISION ENTITY FOR WHICH DATA ARE COLLECTEO

FUNDS (IM. IF) =NEW FIINOS ARRIVING IN MUNTH IM FOR PROGRAM APROG(IE)

GSFTE (IM IE) =NIJMRER OF NON-PROFESSIONAL EMPLOYFES (FULL TIME EQUIVALENT) FOR GROUP-PROGRAM ENTITY IE IN MONTH IM

IMCOL III $=$ II-TH MONTH IN WHICH COST OF LIVING FACTOR IS TO BF. APPLIED IMFUND (II) $=I I-T H$ MONTH IN WHICH FUNUS ARRIVE

KONCAR(IE) $=0$ IF NO CARRYOVFR OF FUNDS FROM ONE FISCAL YEAR TO NEXT FOR GROUP-PRNGRAM ENT ITY IE

KONFAC $=1$ IF AVERAGE RAT:O OF INDIRECT TO (SALARY + WAGES) FROM ALREAOY ACCOUNTEU MONTHS 1 "LAMON IS TO BE PROJECTEO TO MONTHS LAMON+ 1 , NM. $=$ ? IF AVEPAGE RATIO OF INDIRECT TO (SALARY +WAGES) FROM ALREADY ACCOUNTEO MONTH LAMON IS TO HE PROJECTED. $=3$ IF INPUT PFIND IS TO AE PROJECTED

KONPRO $=0$ IF PRDJECTING FOR GROUP. $=1$ OTHERWISE

KONSAL $=1$ IF AVERAGE SALARY PER SMFTE IS TO BE PROJECTEO AS AVERAGE OF ALREADY ACCOUNTED MONTHS 1 ,LAMON. $=2$ IF AVERAGE SALARY PER SMFTE IS TO BE PROJECTED FROM LAST ACCOUNTED MONTH LAMON. $=3$ IF INFUT PAVSAL IS TO $G E$ PROJECTED OR IF KONFRO=1 IHEN AVSALP(IE) IS PROJECTEO AS INPUT FOR EACH IE. AVERAGE WAGES PER GSFTE AKE PROJECTED WITH SAME CONTROLS

LAMON=LAST ACCOUNTEO MONTH BEFURE FORECAST

NC=NUMBER OF CATEGORIES IN M+S

NE $=$ NUMBER OF GROUP-PROGRAM ENTITIES IN PLAN

NFY $=$ CIIRRENT FISCAL YEAR NUMBER

NM=NUMABR OF MONTHS IN PROJECTION

NMCOL =NUMHER OF MONTHS COST OF LIVING FACTORS ARE TO BE APPLIED NMFIJNO=NUMBER OF MONTHS IN WHICH NEW FUNOS ARRIVE FOR A PROGRAM PAVSAL =PROJECTEU AVERAGE SALARY PER PROFESSIONAL STAFF MEMBER PAVWGS=PROJECTED AVERAGE WAGES PEK GS (FTE) PFIND=PROFECTEU INDIHECT FACTOR

SAL (IM. IE) $=S A L A R I E S$ IN MONTH IM FOH ENTITY IE

SMF IF (IM. IF) =NUMHFR OF PROFESSIONAL STAFF MEMBFRS (FULL TIME EQUIVALENT) FOR GRDUP-PROGRAM ENTITY IE IN MONTH IM

SM(IM.IE.IC) =MATERIALS AND SERVICFS COSTS FOR FNTITY IF IN MONTH IM DF CATEGOHY IC.

TEMP (IC) , TEMPI , TFMP 2, ETC TFMPORAR IES

WGS $(I M, I E)=$ WAGES IN MONTH JM FOR ENTITY IE 
LASL GAOUP GXXI $10 / 5 / 73$

$$
2
$$

$.170000 E+01 \cdot 700000 E+00 \cdot 500000 E+00,106000 E+0 \overrightarrow{1}$

0

$.800 Q \bar{Q} 00 E+01.800000 E+01.800000 E+01.800000 E+01.800000 E+\overline{1} 1.800000 E+01$

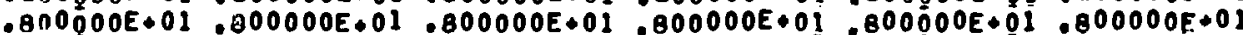

$.700000 E+01: .700000 E+01.700000 E+01.700000 E+01.700000 E+01.700000 E+01$

$.700000 E+01.700000 E+01.700000 E+01.700000 E+01.700000 E+01.700000 E+01$

$.200000 E+01.200000 E+01.200000 E+01.200000 E+01.200000 E+01.200000 E+01$

$.200000 E+01: 200000 E+01.200000 E+01: 200000 E+01.200000 E+01.200000 E+01$

$.100000 E+01.105000 E+01.100000 E+01.100000 E+01.100000 E+01.100000 E+01$

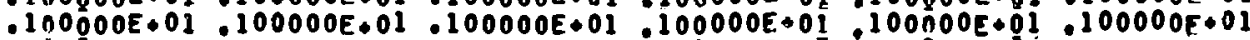

$.300000 E+01.300000 E+01.300000 E+01.300000 E \bullet 01.300000 E+01.300000 E \bullet 01$

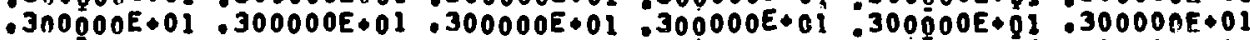

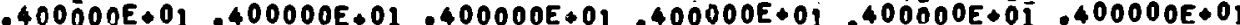

$\because 40000$ \& $01: 400000 E+01: 400000 E+01: \$ 00000 E+01: \$ 00000 E+01, \$ 00000 E+01$

0.00 .00 .000$.

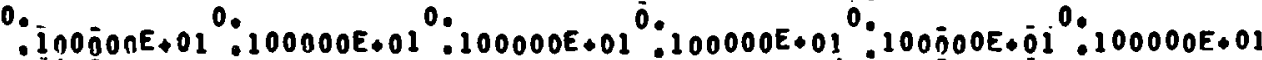
$.100000+01.100000 E+01.100000 E+01.100000 E+01.100000 E+01.100000 E+01$ $G \times \times 1$ PXXI

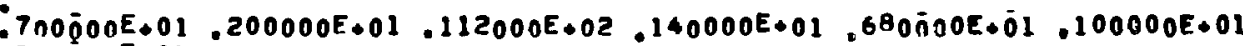
$.2 B 0000 E+01$

$.700000 E+01.200000 E+01.112000 E+02.140000 E+01.080000 E+01.120000 E+01$ $.240000 E+01$

$.800000 E \bullet 01.200000 E+01.126000 E+02.140000 E+01.700000 E+0 j 1.150000 E+01$

.290000 .01

$6 \times \times \overline{1}$

$p \times \times 2$

$.250000 E+02$

$.300000 E+010$.

$130000+01$

$.300000 E+010$.

$.150000 E \bullet 01$

.300000E.010.

$1140000 E \bullet 01$

$.528736 E+00.528736 E+00$

$.500000 E+00: 500000 E+00$

$.480000 E+010$.

$.480000 E+01 \tilde{0}$.

$.510000 E \bullet 010$.

$.500000 E+00.500000 E+00$

$.500000 E+00,500000 E+00$

$.160000 E \cdot 01 \cdot 160000 E \bullet 01$

$.160909 E+01$. 160909E•01

$.170564 E+01: 170564 E \bullet 01$

$.170564 E+01.170564 E+01$

$.160000 E+0 \mathrm{~L}, 160000 E+01$

160909E+01.160909E+01

$.170564 E+01.170564 E+01$

$.170564 E+01.170564 E+01$

$.700000 E+00 \quad .700000 E+00$

$.700000 E+00 \quad 700000 E+00$

$.742000 E+00,742000 E+00$

.7420OOE 00 - $742000 E+00$

$.700000 E+00.700000 E+00$

$.700000 E+00.700000 E+00$

$.742000 E+00-742000 E+00$

$.742000 E+00.742000 E+00$

TIOO 2

$.310000 E_{0} 03$

$.270000 E+03$

2

$.120000 E+03$

$.170000 E+03$ 13

17
$.2400000 E \bullet 01 \cdot 2000005 * 00$

$.2400000+\overline{0} 1 \cdot 400000 E+00$

$.2550000 E+0 \overline{1}, 300000 E+00$

$.500000 E+00.500000 E+00.5000000$. $000.500000 E+00$ $.500000 E+00: 500000 E+00.500000 E+00.500000 E+00$ $.500000 E+00.500000 E+00.500000 E+00.500000 E+00$ $.500000 E+00.500000 E+00.500000 E+00 \quad .520000 E+00$ $.157500 E+01.160909 E * 01.160909 E+01 \cdot 160909 E+01$ $.160909 E+01.160909 E+01.160909 E+01,160909 E+01$ $170564 E+01: 170564 E \cdot 01: 170564 E \cdot 0 \tilde{I}: 1705645+01$ $170564 E+01,170564 E+01,170564 E+01,170564 E+01$ $.170000 E+01: 160909 E+01: 160909 E+01.160909 E+01$ $.160909 E+01 \cdot 160909 E+01 \cdot 160909 E+01 \cdot 160909 F+01$ $.170564 E+01,17 D 564 E+01.170564 E+01.170564 E+01$ $170564 E+01 \quad 170564 E+01.170564 E+01.170564 F+01$ $.700000 E+00.700000 E+00.700000 E+00.700000 E \bullet 00$ $.700000 E+00 \quad .700000 E+00.700000 E+00.700000 F+00$ $742000 E \bullet 00: 742000 E+00: 742000 E \bullet 00: 742000 E+00$ $.742000 E+00: 742000 E+00: 742000 E+00: 742000 E+00$ TO0000E $000.700000 E+00.700$ NOOE $+00.700000 F+00$ $.700000 E+00: 700000 E+00 \quad 700 \overline{0} 00 E+00.700000 E+00$ $742000 E+00.742000 E+00: 742000 E \bullet 00.742000 E+00$ $.742000 E+00,742000 E+00,742$ TOOE+00:742000F+00 


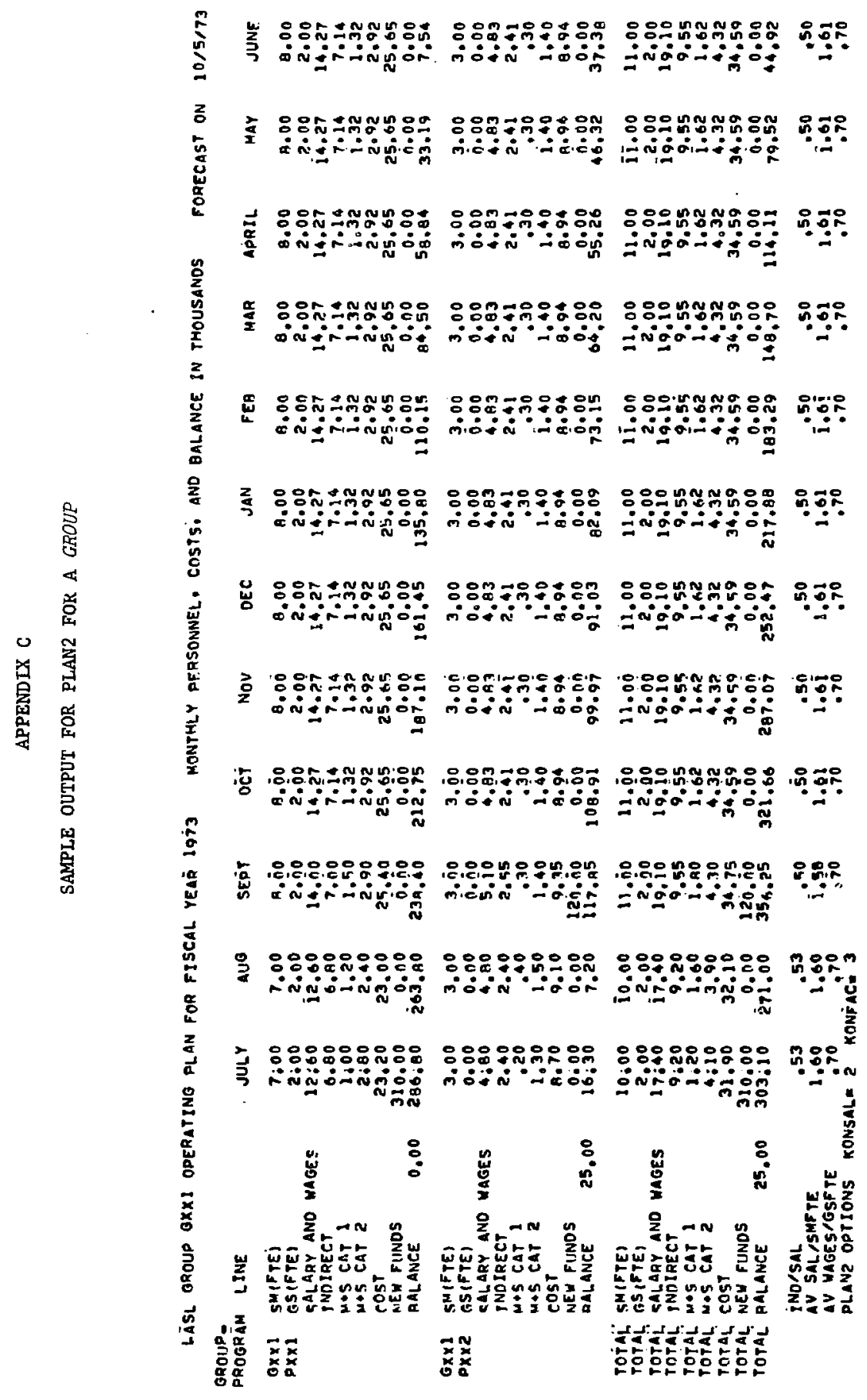




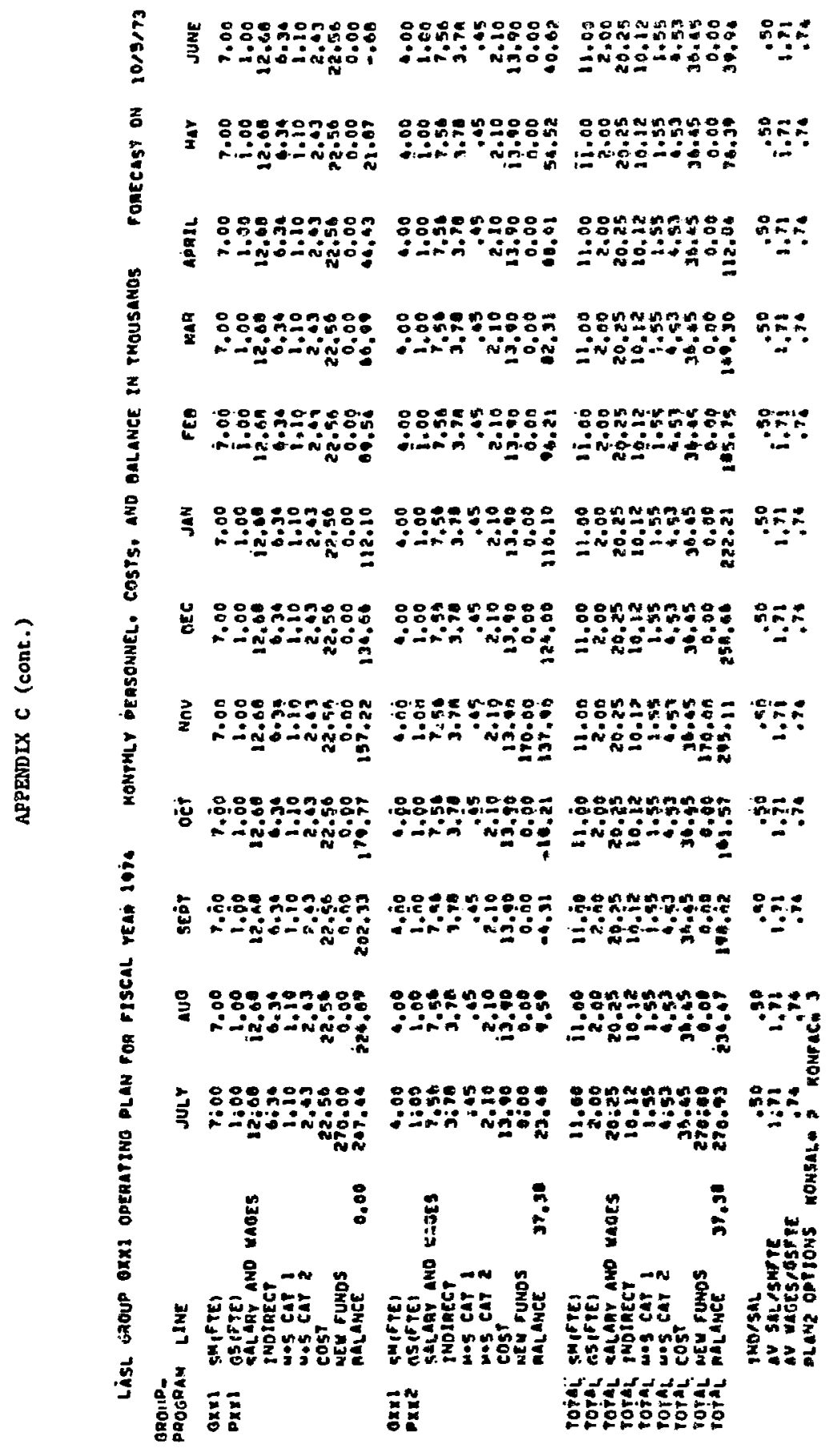




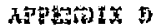

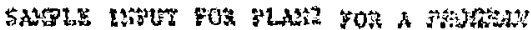

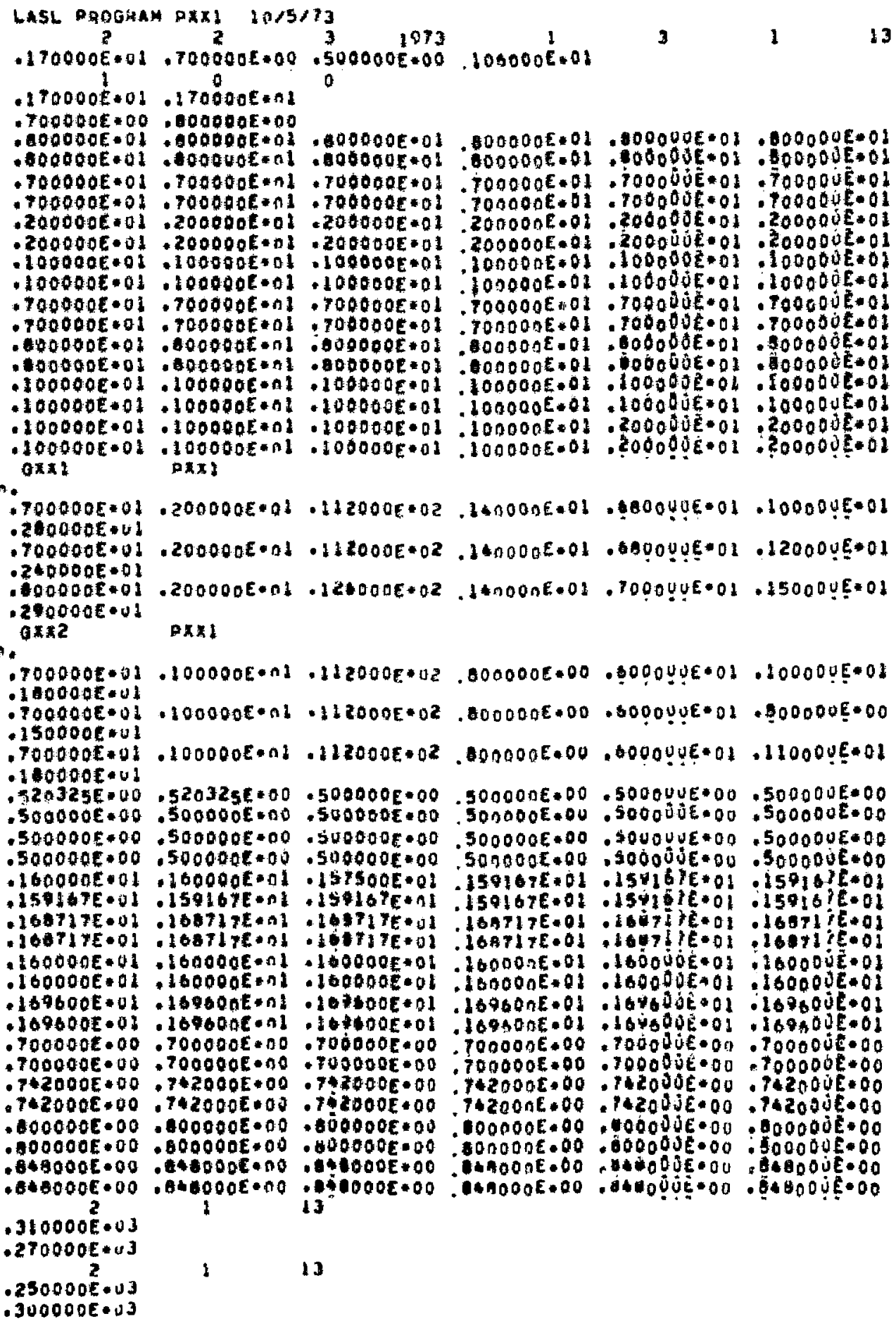


APPEADIX E

SAMPLE OUTPUT FOR PLAN2 FOR A BHOCOAN

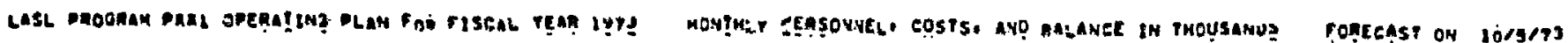
SHolp.

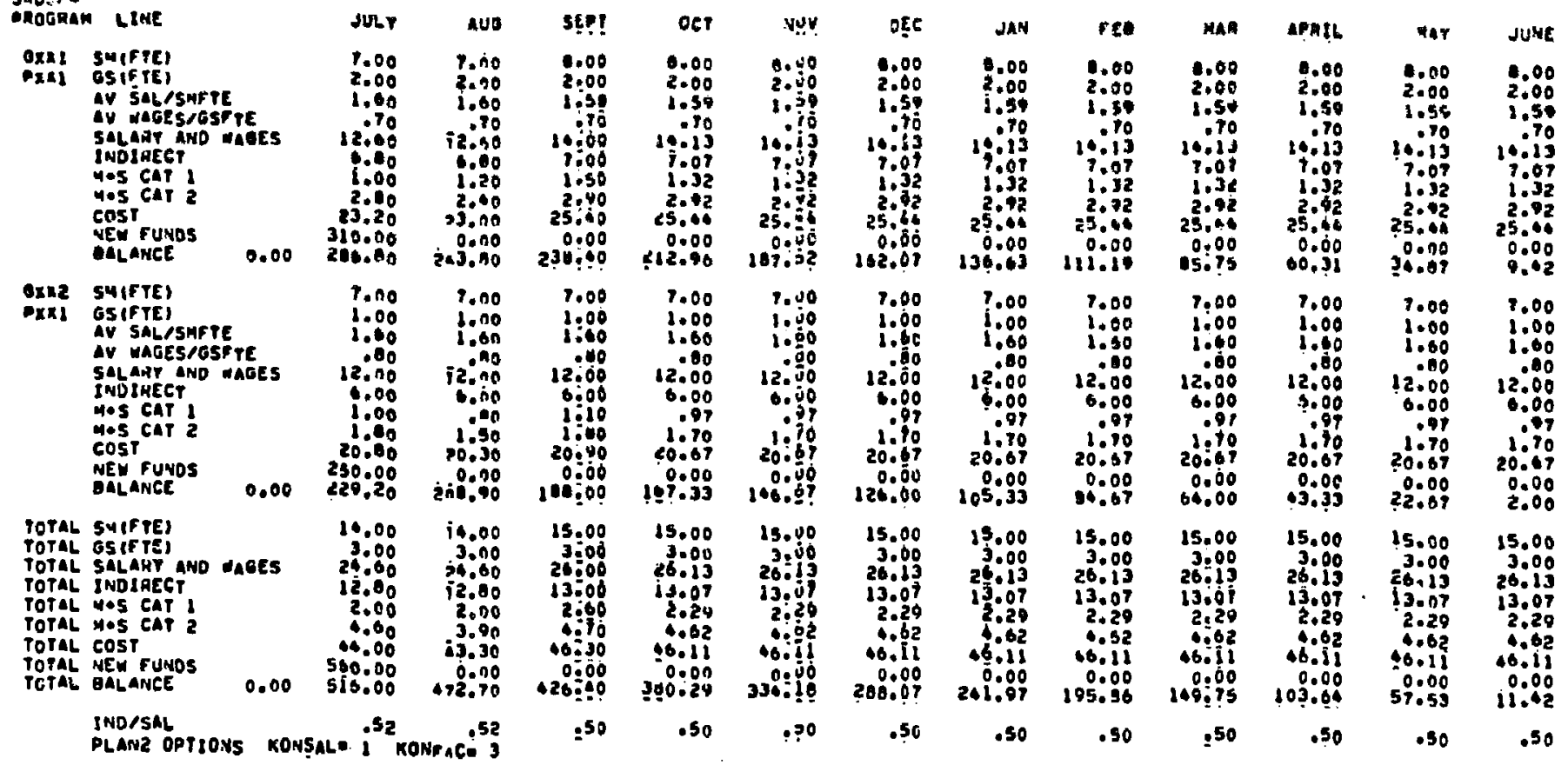




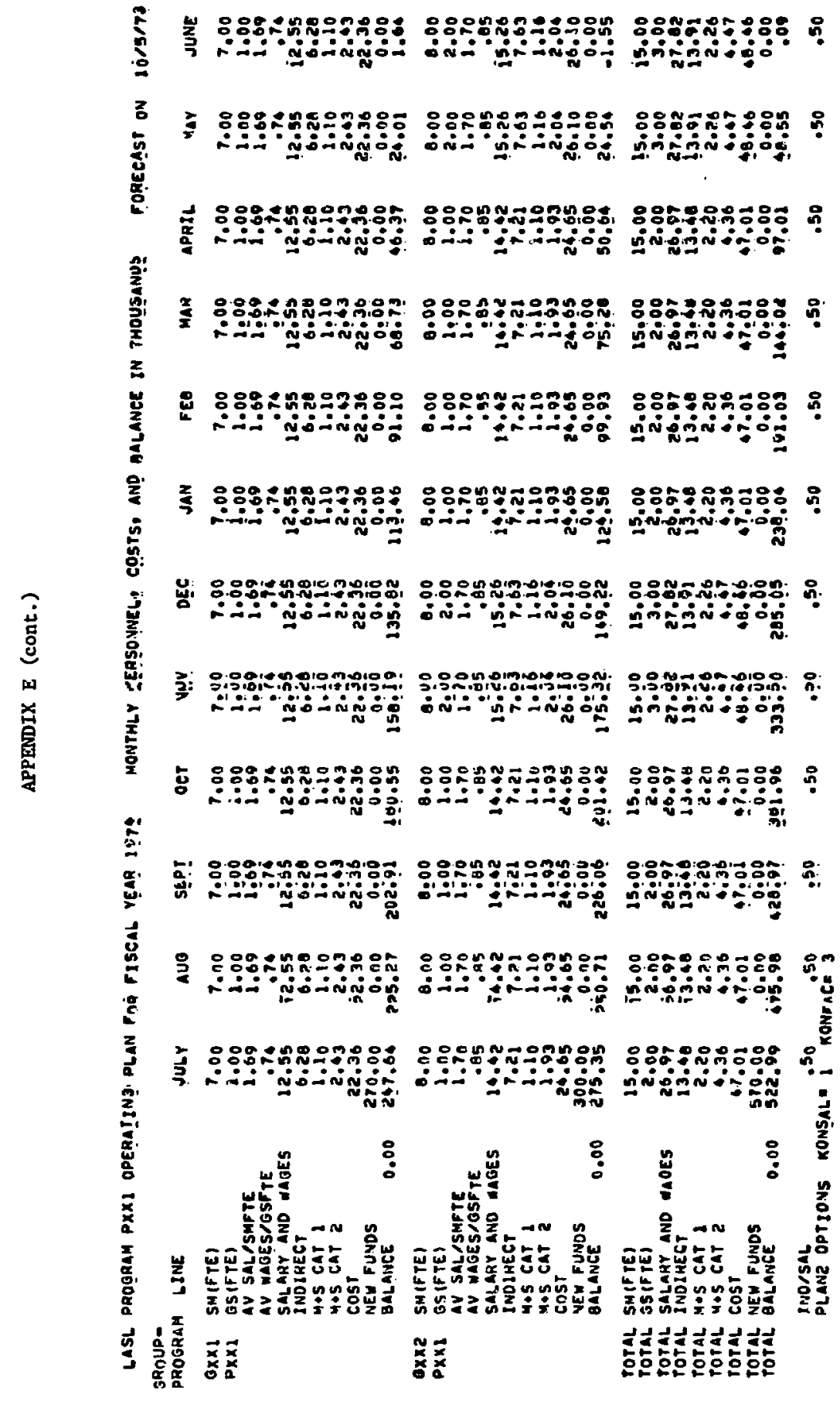

ALT: 349 (110) 